\title{
Enterotoxigenic and enteroaggregative
} Escherichia coli: prevalence, pathogenesis and murine modefis

Diana Ríos-Muñiz, ${ }^{1,2}$ Jorge Francisco Cerna-Cortés, ${ }^{1}$ Nadia Morán-García, ${ }^{2}$ Mario Meza-Segura ${ }^{2}$ and Teresa Estrada-García ${ }^{2 *}$

${ }^{1}$ Departamento de Microbiología, Escuela Nacional de Ciencias Biológicas, Instituto Politécnico Nacional; ${ }^{2}$ Departamento de Biomedicina Molecular, Centro de Investigación y de Estudios Avanzados del Instituto Politécnico Nacional (CINVESTAV). Ciudad de México, México

\begin{abstract}
Enterotoxigenic (ETEC) and enteroaggregative Escherichia coli (EAEC) pathotypes are important etiological agents causätive of diarrhea in children younger than 5 years of age in Mexico and in developing countries, where they cause numerous deaths. Both have been associated with delayed growth in children and are the main causative agents of traveler's diarrhea. The pathogenesis of both bacteria starts by adhering to the intestinal epithelium by means of fimbriae, called colonization factors in human ETEC isolates and aggregative adherence fimbriae in EAEC isolates. Once ETEC adheres to the enterocyte, it produces one or both of its toxins and induces the secretion of chloride and sodium ions and water into the intestinal lumen, producing its characteristic watery diarrhea. EAEC binds to the intestinal epithelium forming a biofilm, induces the production of mucus, releases its toxins and promotes inflammation. EAEC and ETEC infection models with wild-type C57BL/6 and CD 40 ligand-deficient mice (with intact microbiota), respectively, revealed that undernutrition and low-zinc diet increases EAEG infection, causing growth retardation, and that ETEC colonizes, persists and induces local and systemic humoral immune response.
\end{abstract}

KEY WORDS: Enterotoxigenic Escherichia coli. Enteroaggregative Escherichia coli. Diarrhea in children. Undernutrition. Murine models.

\section{Introduction}

In Mexico, diarrheal diseases are the second cause of morbidity in children younger than five years. ${ }^{1}$ These diseases have a mortality rate in children younger than one year of 27.78 , and in children aged one to four, 3.47 per 100,000 children. ${ }^{2}$ After the introduction of the rotavirus vaccine in 2007 , mortality due to diarrhea has decreased; 3 however, morbidity rates have not been significantly modified. ${ }^{1}$

In Mexico, ${ }^{4,5}$ as in the rest of the world, diarrheagenic Escherichia coli pathotypes (DEPs) are recognized as the main etiological agents causative of diarrhea in children. ${ }^{6-11}$ So far, based on their pathogenicity characteristics, six categories are recognized: ${ }^{11}$
- Typical and atypical enteropathogènic Escherichia coli.

- Enterotoxigenic Escherichia coli (ETEC).

- Enteroagregative Escherichia coli (EAEC).

- Diffusely adherent Escherichia coli.

- Shiga toxin-producing Escherichia coli.

- Entero-invasive Escherichia coli.

Unfortunately, DEPs deliberate search is generally not performed, since traditional biochemical tests gnly indicate the species, and characterization is therefore carried out with molecular methods by identifying each pathotype's different loci. ${ }^{12,13}$

In Mexico, after the introduction of the rotavirus vaccine, in a four-year study of deliberate search for patthogens causative of acute diarrhea in children $\bar{w}$ ho
Correspondence:

*Teresa Estrada-Garcia

E-mail: testrada @ cinvestav.mx
Date of reception: 28-09-2018

Date of acceptance: 24-01-2019

DOI: 10.24875/GMM.M19000306 
Table 1. Prevalence of diarrheagenic Escherichia coli pathotypes in different studies carried out in Mexico

\begin{tabular}{|c|c|c|c|c|c|c|c|c|c|c|c|c|}
\hline \multirow[t]{2}{*}{ Region } & \multicolumn{8}{|c|}{ Acute diarrhea requiring hospitalization } & \multicolumn{4}{|c|}{ Community-acquired diarrhea } \\
\hline & \multicolumn{2}{|c|}{$\begin{array}{l}\text { Mexico City- } \\
\text { Tabasco }{ }^{4}\end{array}$} & \multicolumn{2}{|c|}{ Mexico City ${ }^{17}$} & \multicolumn{2}{|c|}{ Yucatán ${ }^{5}$} & \multicolumn{2}{|c|}{ Yucatán ${ }^{5}$} & \multicolumn{2}{|c|}{$\begin{array}{l}\text { Peri-urban } \\
\text { community } \\
\text { (Mexico City) }\end{array}$} & Sinaloa & 5 \\
\hline Period & \multicolumn{2}{|c|}{$\begin{array}{l}\text { March 2000- } \\
\text { February } 2001\end{array}$} & \multicolumn{2}{|c|}{$\begin{array}{l}\text { September 2004- } \\
\text { December } 2006\end{array}$} & \multicolumn{2}{|c|}{$\begin{array}{c}\text { January 2007-2009, } \\
\text { January 2010- } \\
\text { December } 2011\end{array}$} & \multicolumn{2}{|c|}{$\begin{array}{l}\text { January } 2010- \\
\text { July } 2014\end{array}$} & \multicolumn{2}{|c|}{$\begin{array}{c}\text { January- } \\
\text { December } 1998\end{array}$} & $\begin{array}{r}\text { January } \\
\text { 2011-Decer } \\
2014\end{array}$ & mber \\
\hline \multirow[t]{2}{*}{ Patients } & \multicolumn{2}{|c|}{$\begin{array}{l}\text { Childre } \\
<5 \text { years }\end{array}$} & \multicolumn{2}{|c|}{$\begin{array}{c}\text { Children }>2 \text { to } \\
<12 \text { years }\end{array}$} & \multicolumn{2}{|c|}{ Children $<5$ years } & \multicolumn{2}{|c|}{$\begin{array}{l}\text { Children } \\
<10 \text { years }\end{array}$} & \multicolumn{2}{|c|}{$\begin{array}{l}\text { Children } \\
<2 \text { years }\end{array}$} & \multicolumn{2}{|c|}{$\begin{array}{l}\text { Children, adults a्and } \\
\text { elderly patients }\end{array}$} \\
\hline & $\mathrm{n}$ & $\%$ & n & $\%$ & n & $\%$ & n & $\%$ & $\mathrm{n}$ & $\%$ & $\mathrm{n}$ & 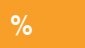 \\
\hline Patient no. & 430 & & 300 & & 831 & $27.9^{\star \star \star}$ & 893 & & $173^{*}$ & & 1037 & 4 \\
\hline Identified DEP & 62 & 14 & 97 & 32.3 & 232 & 9 & 276 & 31 & 32 & 27 & 242 & \\
\hline ETEC & 17 & 26 & 40 & 41.2 & 21 & 24 & 35 & 12.7 & 12 & 37.2 & 43 & \\
\hline EAEC & 16 & 26 & - & & 56 & 20 & 56 & 20.3 & - & & 126 & \\
\hline EPEC & 16 & 26 & 28 & 28.8 & 46 & 0.4 & 49 & 17.7 & 16 & 50 & 53 & \\
\hline STEC & 11 & 18 & 26 & 26.8 & 1 & 35 & 0 & 0 & 1 & 3.1 & 3 & 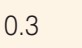 \\
\hline DAEC & - & & - & & 81 & 0.4 & 101 & 36.6 & - & & 15 & 4 \\
\hline EIEC & 2 & 3 & 3 & 3 & 1 & 10 & 2 & 0.7 & 3 & 9.3 & 2 & 0.2 \\
\hline Mixed ${ }^{\star \star}$ & 0 & 0 & 0 & 0 & 23 & & 33 & 12 & 0 & 0 & 0 & \\
\hline $\begin{array}{l}{ }^{*} \text { Diarrhea episodes in } \\
{ }^{* *} \text { More than one DEP } \\
{ }^{* \star *} \text { In three patients, hy } \\
\text {-Not searched, DEP } \\
\text { Escherichia coli, STEC }\end{array}$ & $\begin{array}{l}\text { a cohe } \\
\text { was id } \\
\text { ybrid } E \\
=\text { diarrh } \\
\text { = Shi }\end{array}$ & $\begin{array}{l}76 \text { childre } \\
\text { ed. } \\
\text { richia coli } \\
\text { enic Esche }\end{array}$ & $\begin{array}{l}\text { trains wer } \\
\text { ichia coli }\end{array}$ & $\begin{array}{l}\text { ted, i.e., a } \\
\text { pes, ETE }\end{array}$ & $\begin{array}{l}\text { ngle strair } \\
=\text { enteroto }\end{array}$ & $\begin{array}{l}\text { tains genes } \\
\text { nic Escheric }\end{array}$ & $\begin{array}{l}\text { acteris } \\
\text { oli, EAE }\end{array}$ & $\begin{array}{l}\text { iwo path } \\
\text { enteroag }\end{array}$ & $\begin{array}{l}\text { es. } \\
\text { ative Es }\end{array}$ & nia coli, EPE & enteropathogenic & 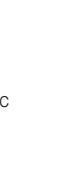 \\
\hline
\end{tabular}

required hospitalization, ${ }^{14}$ DEPs (Diarrheagenic Escherichia coli pathotypes) were observed to be the most commonly identified pathogens in cases of diarrhea (30.9\%), above rotavirus $(22.6 \%)$, Salmonella enterica (11.4\%), Shigella spp. (10.8\%), Campylobacter spp. (5.6 $\%)$, parasites (4.2\%) and Vibrio cholerae (1.1\%). ETEC and EAEC are among the main agents causative of diarrhea and infections, mainly in children from low- and middle-income regions, ${ }^{6-9}$ including Mexico, ${ }^{4,5,14-17}$ as shown in Table 1. In addition, in Mexico, DEP strains have been recorded to be resistant to first-choice antibiotics for the treatment of severe acute diarrhea., ${ }^{4,15}$

The ETEC strains that cause disease in humans are not isolated or cause disease in animals and vice versa; therefore, they are regarded as species-specific, ${ }^{18}$ while EAEC strains have only been isolated in humans. ${ }^{19}$ Thus, little is known so far about in vivo and in situ pathogenesis of both these pathotypes, partially due to the lack of adequate and accessible animal models of infection with ETEC and EAEC strains isolated from humans.

The advantage of using mouse models is that there is a large number of commercial reagents against a great diversity of murine molecules. We expect that EAEC and ETEC murine models allow establishing the immune response they induce in the host and the harm they cause, as well as the bacterial moleculles that induce protective responses in order to use them in the development of vaccines. Therefore, the purposes of this review are to briefly describe the epidemiology of both these pathotypes in general and in particular in Mexico, as well as their pathogenesis and the status of the development of murine models against these pathogens.

\section{ETEC Epidemiology}

This pathotype is an important diarrhea causative agent, responsible for numerous cases and deaths in children younger than five years in regions of the world with middle and low income; it is estimated that it produces one billion cases of diarrhea per year, 810 and attributable mortality in this age group in $2015^{\text {was }}$ $23,600\left(9,600\right.$ to $44,300,95 \%$ uncertainty intervat). ${ }^{20}$

ETEC also affects the adult population, since it is the main etiologic agent, closely followed by EAEC, 
which causes diarrhea in adult travelers from industrialized countries, visiting ETEC and EAEC endemic areas. ${ }^{21,22}$ Approximately 3 to $17 \%$ of adults with travelers' diarrhea subsequently develop inflammatory bowel disease. ${ }^{22}$

In Mexico, using molecular methods, our working team and other researchers have demonstrated the prevalence of ETEC in different regions of the country, particularly in children ${ }^{4,5,14-17}$ (Table 1), but also in adult travelers visiting Mexico. ${ }^{23}$

Given that ETEC causes high mortality in children of endemic areas, ${ }^{9,20}$ and since it has been associated with stunting, ${ }^{24}$ the World Health Organization, through the Product Development for Vaccines Advisory Committee, considers the development of vaccines against this pathogen to be a priority, since one of its goals for 2025 is to reduce pneumonia and diarrhea mortality rates in children younger than five years to less than one per 1000 live births. ${ }^{20}$ The impact of developing enteric vaccines has been clearly established with the introduction of the rotavirus vaccine in children's vaccination schedules, since diarrhea-attributable deaths in children younger than five years in Mexico are estimated to have decreased $34 \%$ between 2005 and 2015. ${ }^{3}$

\section{ETEC pathogenesis}

ETEC pathogenesis, as in any microorganism, requires colonization or infection and subsequent release of its mediators in order for them to act on the host cell. ETEC is defined by the production of heat-labile (LT) and heat-stable (ST) toxins, which are encoded in plasmids whose structure and mechanisms of action are well established. ${ }^{25,26}$ ETEC adhesion to enterocytes is mediated by fimbriae, which are also encoded in plasmids; in human ETEC strains, these fimbriae are called colonization factors. So far, more than 30 colonization factors have been described in different ETEC strains, and it is these fimbriae that confer ETEC its species specificity. ${ }^{27}$

An adhesin called etpA has also been described, which is a glycoprotein secreted by a two-component secretion system called etpBAC that has a very particular function, since it forms a molecular bridge between highly-preserved regions of the flagellin present at the tip of ETEC's flagellum and the host cell surface. Furthermore, in murine models, etpA has been shown to be necessary for colonization of the small intestine and in epithelial cell lines and for proper adhesion and release of the LT toxin. ${ }^{25,26}$

Once ETEC binds to intestinal mucosa, it releases its toxins, which results in watery diarrhea similar to that of cholera, which is characteristic of this pathogen. ${ }^{25,26} \mathrm{LT}$ toxin is closely related in structure and antigenicity with the cholera toxin, it has a molecullar mass of $84 \mathrm{kDa}$ and is composed of two subunits. The active subunit $(A)$, surrounded by five identical $B$ subunits, which are bound. ${ }^{25}$ On the other hand, ST toxin is a low molecular weight peptide composed of 18 or 19 amino acids and has two variants, pST and hST, named like this because the former was described in pigs and the latter in humans. Both toxins finally phosphorylate the cystic fibrosis transmembrane regua âtor (CFTR) channel, stimulating chloride ions secretion, which entails salts and water secretion from the enterocyte towards the intestinal lumen. ${ }^{25}$ The production of any of both these toxins is sufficient to cause severe diarrhea, and epidemiological studies have shown that ETEC strains can produce LT toxin $\mathrm{ST}$ toxin or both-10,14-17 Other pathogenicity factors have been described; however, most of them have only been described in the prototype strain. So far, onty in ETEC strains has the auto-transporter with serine protease activity called EatA been described, which seems to accelerate LT output, since it degrades MUC2, the main mucin secreted by intestinal calciform cells, and etpA-mediated modular adhesion:

\section{ETEC murine Models}

Murine models have become an essential toot to understand the complex interaction between enferic microorganisms and their host and disease. Due to the relevance of intestinal microbiota, ${ }^{28,29}$ the devefopment of murine models of any enteric pathogen must include an intact resident microbiota, since, in them, antibiotics have been shown to modify intestinal tract resident microbiota, including those that are broad-spectrum, which alters carbohydrate availability in the intestinal mucosa, which is taken advantage by intestinal pathogens such as Salmonella enterica serovar typhimurium and Clostridium difficile. ${ }^{28}$ In addition, the composition of microbiome in mice, both wild type and those used in disease models, has recently been shown to vary depending on the animal "care facility and this may explain the poor reproducibility of murine models in different laboratories. ${ }^{29}$

Since several decades ago, attempts have been made to develop a murine model with ETEC protofype strain H10407 (serotype O78:H11), isolated from an adult patient with severe diarrhea in Bangladesh. This strain contains two plasmids, one that encodes for $T L$ toxin and another one for ST toxin, with the latter 
plasmid also encoding for the first colonization factor ever described, which was called CFA/I, which is why it is known as ST-CFA/I plasmid.

Dr. Fleckestein ${ }^{30}$ working group has successfully used mice of the CD1 strain to study colonization of the ETEC H10407 wild strain and of its It and etpA mutants only for 24 hours post-infection. Actually, in these studies, the small intestine of mice has been used as a test tube, since prior to inoculation with wild or mutant strains, as in many other studies, mice receive broad spectrum antibiotics, which causes elimination of the gut microbiota. Recently, a murine model with a C57BL/6 mouse was used to assess the effect of zinc on infection with ETEC H10407, both in animals with normal diets and with low-protein and zinc-deficient diets; however, prior to ETEC oral inoculation, the animals were treated with antibiotics, which altered intestinal microbiota. ${ }^{24}$

Therefore, murine models that preserve the microbiota intact, where assessing ETEC interaction with the intestinal epithelium, its colonization and persistence in vivo and in situ can be possible, should be developed. In 2013, we reported for the first time a murine model of infection and persistence with the CD40 ligand-deficient C57BL/6 mouse strain (C57-cd4OH ${ }^{-}$) and ETEC H10407 (which contains the LT and ST-CFA/I plasmids), which was orally inoculated without prior antibiotic treatment. ${ }^{18}$ We demonstrated that ligand-deficient mice remained colonized for more than 15 days after infection in comparison with wild type mice (C57BL/6), which cleared ETEC at three days post-infection. Both the wild type and the $\mathrm{C} 57-\mathrm{Cd}_{4} \mathrm{OH}^{- \text {- }}$ mice were able to produce antibodies of the specific $\lg M, \lg G$ and $\lg A$ classes against ETEC in serum and feces, but at significantly lower concentrations in the $\mathrm{C} 57-\mathrm{Cd}_{40 \mathrm{O}^{--}}$mice. In order to assess the role of ETEC H10407 plasmids in infection, groups of wild type and $\mathrm{C} 57-\mathrm{Cd}_{40 \mathrm{O}^{-}}$mice were orally inoculated with the $\mathrm{H} 10407$ wild strain and with two variants of the strain: one lacking the LT plasmid (only with the ST-CFA/I plasmid) and another lacking the ST-CFA/I plasmid (only with the LT plasmid). As expected, wild type mice eliminated all bacterial strains at three days post infection, while the $\mathrm{C} 57-\mathrm{cd}_{40} \mathrm{O}^{-}$mice eliminated the strain that only contained the ST-CFA/I plasmid at 31 days and they remained colonized both with ETEC wild type strain and with the strain that only contained the LT plasmid until day 113 , when they were sacrificed. ${ }^{18}$ This suggested that for $\mathrm{H} 10407$ persistence in the CD40 ligand-deficient mouse, the presence of LT plasmid is necessary, and this model can therefore be used to study the interaction of ETEC strains isolated from humans in vivo and in situ.

\section{EAEC Prevalence}

EAEC is a pathogen that thus far has only been identified in humans; it is characterized for grouping together in the form of stacked bricks, either on epithelial cells or on crystal. ${ }^{31}$ This pathotype was isolated from a Peruvian child with acute diarrhea. Based on the presence of the aggR master regulator, first described in the 042 archetype strain (O44:H18 serotype), which regulates several pathogenicity geñes, EAECs are classified as typical and atypical (tEAEC and $\mathrm{aEAEC}) .{ }^{19,31}$ Clinical characteristics of the disease caused by EAEC have been basically described ffom studies in adult volunteers, outbreaks and sporădic cases; these strains produce watery diarrhea, often with mucus, with or without blood, fever, abdominal pain, nausea and vomiting. . $^{3,19}$

The search for tEAEC has been carried out since several years ago by identifying the gene thatencodes for the aggR transcriptional regulator; this bacterium has been found to be associated with episodes of acute and persistent diarrhea in children younger than five years, ${ }^{4-8,14,15}$ and, in addition, it is the second agent most frequently isolated from travelers' diarthea episodes in adults. ${ }^{21,23}$

In children from developing and underdeveloped countries, EAEC infection has been associated with intestinal inflammation and malnourishment, as well as with growth and cognitive function decrease ${ }^{31} 1_{35}$ tEAEC has also been isolated in HIV-infected children from less developed regions. ${ }^{31}$ In Mexico, EAEC has been identified in children with diarrhea that requitred hospitalization, ${ }^{4,5,14}$ as well as with communitycacquired diarrhea ${ }^{15}$ (Table 1); recently it was significantly associated with acute diarrhea in children younger than two years in Sinaloa. ${ }^{15}$ This observation is portant because studies carried out in the last decade in underdeveloped countries of Asia and Affrica showed that the prevalence of EAEC infection is similar in children with and without diarrhea, ${ }^{9,10}$ which reveals that EAEC epidemiology is different depending on the populations and their socioeconomic conditions and that it should not be generalized.

\section{EAEC pathogenesis}

Several studies have suggested that EAEC genesis is divided in three stages: 
- Adhesion to intestinal mucosa mainly mediated by aggregative adhesion fimbriae

- Release of enterotoxins and cytotoxins.

- Induction of mucosal inflammation. ${ }^{31}$

EAEC characteristic phenotype, aggregative adherence, is due to aggregative adherence fimbriae; however, in different EAEC strains, it has also been associated with other fimbrial and afimbrial-type adhesins. The heterogeneity of the variety of fimbriae is similar to that observed in ETEC colonization factors. ${ }^{27,31}$ Aggregative adherence fimbriae are encoded in a plasmid of high molecular weight, where in the 042 strain, in addition to the gene for aggregative adherence fimbria II, the genes that encode for several molecules involved in the pathogenesis of this bacterium are also found, ${ }^{31}$ such is the case of plasmid-encoded toxins (Pet), the target of which are alpha-fodrine and EAST-1, with the latter being an EAEC heat-stable toxin whose activity is similar to that of ETEC ST toxin, since it also binds to the guanylate cyclase receptor on the membrane of host enterocytes. This plasmid also contains the genes for the cryptic protein shf and the anti-aggregative secreted protein (aap), whose products are required for the formation of EAEC characteristic biofilm and of a protein that covers the bacteria in order for it to be able to disperse through the mucus and reach the surface of enterocytes, respectively. ${ }^{31}$ Very importantly, in the same plasmid is the encoded aggR gene, whose product is the master transcriptional regulator, which modulates the expression of all genes of the described molecules.

EAEC produces other toxins with cytotoxic effect such as the shigella enterotoxin 1 (ShET1) and protease involved in intestinal colonization (Pic) toxins, both encoded in the bacterial chromosome. So far, no molecules exclusively associated with EAEC strains isolated from cases of diarrhea have been identified, and identification of molecules that characterize virulent strains therefore continues to be an area of great scientific interest. EAEC strains isolated from cases of diarrhea have been reported to form biofilms more often than strains isolated from subjects with no diarrhea. ${ }^{36}$ Up to $67 \%$ of tEAEC strains isolated from severe cases of diarrhea contain the genes that encode for the Pic and ShET1 toxins. ${ }^{14}$ In children with persistent EAEC infection, chronic intestinal inflammation has been shown to be induced in the absence of diarrhea while, in the feces of subjects with diarrhea due to tEAEC, lactoferrin and other inflammation markers have been identified. ${ }^{8,31}$ Based on the above, EAEC infection is believed to induce inflammation in the intestine of children and adults, which results in damage to the intestinal epithelium, thus decreasing the absorption capacity, which entails a decrease in nutrient absorption and, therefore, malnourishment, particularly in children from underdeveloped countries, ${ }^{8.31}$ thus maintaining the vicious circle of diarnhea and malnourishment.

\section{Murine EAEC Models}

Due to the lack of adequate and accessible $E \bar{A} E C$ animal models, EAEC pathogenesis in vivo and in situ is thus far unknown, i.e., the mechanisms underlying its onset, progression and outcome in vivo, as Philipson et al. ${ }^{37}$ mentioned in their 2013 review, since in the murine models reported up to that moment, lëcal microbiota, which is essential to intestinal homeostasis, ${ }^{38}$ was always eliminated, and whether EAEC infection induced alterations in situ had not beencassessed. Furthermore, with these models, it cannot be established if intestinal disorders are due to EAEC infection and not to the absence of local microbiöta.

In 2010, an infection model was describe $\bar{c}$ in C57BL/6 adult mice, where two EAEC reference strains, 042 and JM221, were analyzed and where, prior to being inoculated, the mice were treated with antibiotics, which is why the authors considered that the model showed limitations. ${ }^{39}$ Subsequently, that same group developed another EAEC infection model, without prior antibiotic treatment and with recently weaned C57BL/6 mice; the effect of EAEC 042 infection was evaluated in malnourished mice or in mice that were previously treated with antibiotics (prior to being inoculated). They observed that both groups of mice showed a significant increase in bacterial infection in comparison with mice without malnutrition that in addition were not treated with antibiotics..$^{40,41}$

Our working group has recently developed a moidel of EAEC 042 infection with C57BL/6 adult mice with intact microbiota, which has allowed to assess the interaction of these bacteria with enterocytes within the first days of infection. We have managed to establish the role of aggregative adherence fimbria in intestinal tract infection using a wild type strain and a mutant aggregative adherence fimbria II strains: have observed that it induces beta catenin mobilization through its binding to the MUC1 protein, which is on the surface of enterocytes. ${ }^{42}$

On the other hand, with a BALB/C mouse model, another group of researchers assessed the effect of two EAEC strains isolated from Indian patients wwith 
diarrhea. ${ }^{8}$ At 10 days post-oral inoculation, the animals showed alterations on the ileum surface, broadening of the microvilli base, and in the lamina propria, of mononuclear cell and neutrophil infiltrates and some hemorrhagic foci. However, the authors do not mention whether the animals were treated with antibiotics prior to inoculation with these bacteria, or the dose of the inoculated bacteria.

\section{Conclusions}

In Mexico, ETEC and EAEC are important causal agents of diarrhea in children younger than five years. EAEC causes diarrhea in children with malnourishment. The pathogenesis and the molecules responsible for watery diarrhea characteristic of ETEC are LT and ST toxins, which are well characterized, while in EAEC they are not yet fully identified, since this bacterium is defined by the presence of a master regulator that modulates several virulence genes. Currently, we have murine models of ETEC and EAEC infection with intact microbiota, which will allow understanding the complex interaction between these pathogens and their host.

\section{Acknowledgements}

For this work, Diana Ríos Muñiz had the support of grant 20160973; Nadia Morán García, of grant 261884 and Mario Meza Segura, grant 243144, all from Conacyt. During this time, Teresa Estrada García had project support 254990, also granted by Conacyt. Jorge Francisco Cerna Cortés is grant holder of the Estímulo al Desempeño de los Investigadores and Comisión de Operación y Fomento de Actividades Académicas programs, both from Instituto Politécnico Nacional.

\section{References}

1. Secretaría de Salud. Anuario de morbilidad 2015. México: Dirección General de Epidemiologia/Secretaría de Salud; 2015.

2. Instituto Nacional de Estadística y Geografía. Estadística a propósito del día del niño (30 de abril). Datos nacionales. México: Instituto Naciona de Estadística y Geografía; 2018.

3. Sánchez-Uribe E, Esparza-Aguilar M, Parashar UD, Richardson V. Sustained reduction of childhood diarrhea-related mortality and hospitalizations in Mexico after rotavirus vaccine universalization. Clin Infect Dis. 2016:62:S133-S139.

4. Estrada-García T, Cerna JF, Paheco-Gil L, Velázquez RF, Ochoa TJ, Torres J, et al. Drug-resistant diarrheogenic Escherichia coli, Mexico. Emerg Infect Dis. 2005;11:1306-1308.

5. Patzi-Vargas S, Zaidi M, Pérez-Martínez I, León-Cen M, Michel-Ayala A, Chaussabel D, Estrada-García T. Diarrheagenic Escherichia coli carrying supplementary virulence genes are an important cause of moderate to severe diarrhoeal disease in Mexico. PLoS Negl Trop Dis. 2015; 9:e0003510.

6. Ochoa T, Ecker L, Barletta F, Mispireta M, Gil A, Contreras C, et al. Age-related susceptibility to infection with diarrheagenic Escherichia coli among infants from periurban areas in Lima, Peru. Clin Infect Dis. 2009; 49:1694-1702.
7. Ochoa TJ, Mercado EH, Durand D, Rivera FP, Mosquito S, Contreras C, et al. Frequency and pathotypes of diarrheagenic Escherichia coli in Peruvian children with and without diarrhea. Rev Peru Med Exp Salud Publica. 2011;28:13-20.

8. Saha DR, Guin S, Krishnan R, Nag D, Koley H, Shinoda S, Ramamurthy T. Inflammatory diarrhea due to enteroaggregative Escherichiácoli: evidence from clinical and mice model studies. Gut Pathog. 2013 5:36.

9. Kotloff K, Nataro J, Blackwelder W, Nasrin D, Farag T, Panchalingam S, et al. Burden and aetiology of diarrhoeal disease in infants and foung children in developing countries (the Global Enteric Multicenter Study, GEMS): a prospective, case-control study. Lancet. 2013;382:209-222.

10. Platts-Mills JA, Babji S, Bodhidatta L, Gratz J, Haque R, Havt A, et al. Pathogen-specific burdens of community diarrhoea in developing countries: a multisite birth cohort study (MAL-ED). Lancet Glob Health.2015; 3:e564-e575.

11. Croxen MA, Law RJ, Scholz R, Keeney KM, Wlodarska M, Finläy BB. Recent advances in understanding enteric pathogenic Escherichia coli. Clin Microbiol Rev. 2013:26:822-880

12. Cerna JF, Nataro JP, Estrada-García T. Multiplex PCR for detection of three plasmid-borne genes of enteroaggregative Escherichia coli strains. J Clin Microbiol. 2003;41:2138-2140.

13. López-Saucedo C, Cerna JF, Villegas-Sepúlveda N, Thompson R Velázquez FR, Torres J, et al. Single multiplex polymerase chain reaction to detect diverse loci associated with diarrheagenic Escherichįcoli. Emerg Infect Dis. 2003:9:127-131.

14. Meza-Segura MA. Caracterización de los factores asociados conta severidad de la diarrea causada por los patogrupos de Escherichia coli. [Tesis doctoral]. México: Centro de Investigación y de Estudios Avánzados-Instituto Politécnico Nacional; 2017.

15. Canizalez-Román A, Flores-Villaseñor HM, González-Núñez E, Velázquez-Román J, Vidal JE, Muro-Amado S, et al. Surveillance of diartheagenic Escherichia coli strains isolated from diarrhea cases-from children, adults and elderly at northwest of Mexico. Front Microbiol.2016; 7:1924.

16. Estrada-García T, López-Saucedo C, Thompson-Bonilla R, Abonce M, López-Hernández D, Santos JI, et al. Association of diarrheagehic Escherichia coli pathotypes with infection and diarrhea among Mexican children and association of atypical enteropathogenic E. coli with Gicute diarrhea. J Clin Microbiol. 2009;47:93-98.

17. Paniagua GL, Monroy E, García-González O, Alonso J, Negrete E, Vaca S. Two or more enteropathogens are associated with diarrhēa in Mexican children. Ann Clin Microbiol Antimicrob. 2007;28;6:17.

18. Bernal-Reynaga R, Thompson-Bonilla R, López-Saucedo C, Pech-Armenta M, Estrada-Parra S, Estrada-García T. C57-CD40 ligand deficient mice: a potential model for enterotoxigenic Escherichia coli (H10407) colonization. Vet Immunol Immunopathol. 2013;152:50-56.

19. Estrada-García T, Pérez-Martínez I, Bernal-Reynaga R, Zaidi M: Enteroaggregative Escherichia coli: a pathogen bridging the north and south. Curr Trop Med Rep. 2014;2:88-96.

20. Hosangadi D, Smith PG, Kaslow DC, Giersing BK, WHO ETEC \& Shigella Vaccine Consultation Expert Group. WHO consultation on ETEC and Shigella burden of disease, Geneva, 6-7 $7^{\text {th }}$ April 2017: Meeting report. Vaccine. 2018;pii: S0264.

21. Jiang ZD, DuPont HL. Etiology of travellers' diarrhea. J Travel Med. 2017;24:S13-S16.

22. Steffen R, Hill DR, DuPont HL. Traveler's diarrhea: a clinical review. JAMA. 2015:313:71-80.

23. Paredes-Paredes M, Okhuysen PC, Flores J, Mohamed JA, Paddä RS, Gonzalez-Estrada A, et al. Seasonality of diarrheagenic Escherichia coli pathotypes in the US students acquiring diarrhea in Mexico. J Iravel Med. 2011;18:121-125.

24. Bolick DT, Medeiros P, Ledwaba SE, Lima AA, Nataro JP, Barry EM, et al. Critical role of zinc in a new murine model of enterotoxigenio Escherichia coli diarrhea. Infect Immun. 2018;86:e00183.

25. Fleckenstein J, Sheikh A, Qadri F. Novel antigens for enterotoxigenic Escherichia coli vaccines. Expert Rev Vaccines. 2014;13:631-639

26. Sahl JW, Sistrunk JR, Baby NI, Begum Y, Luo Q, Sheikh A, et al. Insights into enterotoxigenic Escherichia coli diversity in Bangladesh ufilizing genomic epidemiology. Sci Rep. 2017;7:3402.

27. Madhavan TP, Sakellaris H. Colonization factors of enterotoxidenic Escherichia coli. Adv Appl Microbiol. 2015;90:155-197.

28. $\mathrm{Ng} \mathrm{KM}$, Ferreyra JA, Higginbottom SK, Lynch JB, Kashyā̄ PC, Gopinath S, et al. Microbiota-liberated host sugars facilitate post-antibiotic expansion of enteric pathogens. Nature. 2013:502:96-99.

29. Parker KD, Albeke SE, Gigley JP, Goldstein AM, Ward NL. Microblome composition in both wild-type and disease model mice is heavily inffuenced by mouse facility. Front Microbiol. 2018:9:1598.

30. Allen KP, Randolph MM, Fleckenstein JM. Importance of heattabile enterotoxin in colonization of the adult mouse small intestine by human enterotoxigenic Escherichia coli strains. Infect Immun. 2006;74:869=875.

31. Estrada-García T, Navarro-García F. Enteroaggregative Escherichía-coli pathotype: a genetically heterogeneous emerging foodborne enteropathogen. FEMS Immunol Med Microbiol. 2012;66:281-298. 
32. Guerrant RL, Oriá RB, Moore SR, Oriá MO, Lima AA. Malnutrition as an enteric infectious disease with long-term effects on child development. Nutr Rev. 2008;66:487-505.

33. Opintan JA, Newman MJ, Ayeh-Kumi PF, Affrim R, Gepi-Attee R, SeviIleja JE, et al. Pediatric diarrhea in southern Ghana: etiology and association with intestinal inflammation and malnutrition. Am J Trop Med Hyg. 2010;83:936-943.

34. Acosta GJ, Vigo N, Durand D, Riveros M, Arango S, Zambruni M, et al. Diarrheagenic Escherichia coli: prevalence and pathotype distribution in children from peruvian rural communities. Am J Trop Med Hyg. 2016:95:574-579.

35. Rogawski E, Guerrant R, Havt A, Lima I, Medeiros P, Seidman J, et al. Epidemiology of enteroaggregative Escherichia coli infections and associated outcomes in the MAL-ED birth cohort. PloS Negl Trop Dis. 2017:11:e0005798.

36. Mohamed JA, Huang DB, Jiang ZD, DuPont HL, Nataro JP, Belkind-Gerson $\mathrm{J}$, et al. Association of putative enteroaggregative Escherichia coli virulence genes and biofilm production in isolates from travelers to developing countries. J Clin Microbiol. 2007;45:121-126.

37. Philipson WC, Bassaganya-Riera J, Hontecillas R. Animal models of enteroaggregative Escherichia coli infection. Gut Microbes. 2013;4:281-291.
38. Koboziev L, Reinoso-Webb C, Furr K L, Grisham MB. Role of the-enteric microbiota in intestinal homeostasis and inflammation. Free Radie Biol Med. 2014;68:122-133.

39. Roche JK, Cabel A, Sevilleja J, Nataro J, Guerrant RL. Enteroagğ̌regative Escherichia coli (EAEC) impairs growth while malnutrition wołsens EAEC infection: a novel murine model of the infection malnutrition Eycle. J Infect Dis. 2010;202:506-514.

40. Bolick DT, Roche JK, Hontecillas R, Bassaganya-Riera J, Nataro JP, Guerrant RL. Enteroaggregative Escherichia coli strain in a novel weaned mouse model: exacerbation by malnutrition, biofilm as a virulence factor and treatment by nitazoxanide. J Medical Microbiol. 2093;62: 896-905.

41. Medeiros P, Bolick DT, Roche JK, Noronha F, Pinheiro C, Kolling GL, et al. The micronutrient zinc inhibits EAEC strain 042 adherence, biofilm formation, virulence gene expression, and epithelial cytokine responses benefiting the infected host. Virulence. 2013;4:624-633.

42. Morán-García NE. Desarrollo y caracterización de un modelo mêrido de infección con Escherichia coli enteroagregativa 042 y la parficipación de la fimbria AAF/II en la infección [Tesis doctoral]. Méxicoscentro de Investigación y de Estudios Avanzados-Instituto Politégnico Nacional; 2018. 